\title{
Seasonal and hormonal control of pulsatile LH secretion in the dairy goat (Capra hircus)
}

\author{
P. Chemineau, G. B. Martin*, J. Saumande and Elisabeth Normant \\ I.N.R.A. Station de Physiologie de la Reproduction, Nouzilly, 37380 Monnaie, France
}

Summary. In Exp. 1, the changes in pulsatile LH secretion at the onset of the breeding season were observed in 20 intact, mature Saanen does. Blood was sampled every $20 \mathrm{~min}$ for $6 \mathrm{~h}$ each week from the beginning of August until the onset of ovulatory activity, as evidenced by cycles in plasma progesterone. The first doe ovulated at the end of August and all were cycling by the end of September. As the first ovulation approached, LH pulse frequency increased by $67 \%$ and mean levels of $\mathrm{LH}$ increased by $47 \%$. These changes were progressive rather than abrupt. In Exp. 2, seasonal changes in the inhibition of pulsatile $\mathrm{LH}$ secretion by ovarian steroids were studied in ovariectomized Saanen does. The animals were untreated $(\mathrm{N}=4)$ or given subcutaneous oestradiol implants $(\mathrm{N}=4)$ and blood was sampled every $10 \mathrm{~min}$ for $6 \mathrm{~h}$, twice during the breeding season and twice during the anoestrous season. In each season, the second series of samples was taken after the animals had been treated with progesterone, administered by intravaginal implants. Season did not significantly affect LH secretion in goats not treated with oestradiol, but LH pulse frequency was $54 \%$ lower during the anoestrous season than during the breeding season in oestradiol-treated goats. Mean LH concentrations were affected in the same manner as pulse frequency, but pulse amplitude was increased by oestradiol treatment in both seasons. Progesterone had no detectable effect on LH secretion in either season. In Exp. 3, the response to repeated melatonin injections at a set time after dawn was investigated in 11 oestradiol-treated, ovariectomized goats. They were placed under a regimen of long days ( $16 \mathrm{~h}$ light: $8 \mathrm{~h}$ dark) and 1 month later 6 of them were injected daily ( $10 \mathrm{~h}$ after 'dawn') with $2 \mathrm{mg}$ melatonin. The other 5 animals served as controls. Blood samples (every $10 \mathrm{~min}$ for $6 \mathrm{~h}$ ) were taken just before and 38 and 72 days after the start of melatonin treatment. As the experiment progressed, LH pulse frequency increased by $20 \%$ in melatonin-treated goats but decreased by $43 \%$ in controls. Mean LH values were maintained in melatonintreated females but decreased in the control group. Melatonin did not affect pulse amplitude.

The results of the experiments with ovariectomized does suggest that seasonal reproductive cycles in the goat are caused by changes in the duration of melatonin secretion at night, which induce alterations in the intensity with which oestradiol inhibits LH secretion. In turn, this may be responsibile for the gradual changes in the frequency of LH pulses observed in entire does. The frequency of LH pulses is one of the most important endocrine signals controlling ovarian activity so would form the final link in the chain connecting environmental and reproductive cycles.

Keywords: LH; goat; melatonin; steroids; season

*Present address: Animal Science Group, School of Agriculture, University of Western Australia, Nedlands, Western Australia 6009, Australia. 


\section{Introduction}

Seasonal changes in the reproductive activity of sheep are governed by changes in the activity of the hypothalamo-pituitary axis. The secretion of gonadotrophins, particularly the frequency of LH pulses, increases before and during the annual breeding season (Scaramuzzi \& Martensz, 1975; Yuthasastrakosol et al., 1977). Studies with ovariectomized ewes bearing oestradiol implants suggest that this is mainly due to changes in the responsiveness of the hypothalamus to negative feedback by ovarian oestrogen (Legan et al., 1977). During the sexual season the hypothalamus shows little response to oestrogen and LH pulse frequency is high, whereas during anoestrus the hypothalamus is very responsive to oestrogen and LH pulse frequency is low (Goodman et al., 1982; Martin et al., 1983). In turn, the seasonal cycles in hypothalamic activity are apparently caused by an effect of photoperiod on the circadian rhythm of melatonin, a pineal hormone which affects the hypothalamic systems controlling the release of pulses of gonadotrophin-releasing hormone (GnRH; Hoffmann, 1981; Bittman, 1984; Herbert, 1984; Karsch et al., 1984; Kennaway, 1984; Hansen, 1985).

As with sheep, the dairy goat is seasonally polyoestrous with a breeding season in autumn induced by changes in photoperiod (Bissonnette, 1941). This similarity led us to suggest that intact female goats would show increased pulse frequency at the onset of the breeding season and that these seasonal changes in pulse frequency were mediated by melatonin-induced differences in responsiveness to gonadal feedback. This article describes three experiments in which we tested these hypotheses.

\section{Materials and Methods}

Animals. The experiments were done on adult female goats of the Saanen dairy breed which were maintained at the INRA Station near Tours $\left(45^{\circ} \mathrm{N}\right)$ where they had ad-libitum access to feed and water. Ovarian activity in the intact goats was monitored by measuring progesterone concentration in blood samples taken twice weekly, using a qualitative assay which allows the detection of a functional corpus luteum (Terqui \& Thimonier, 1974; Thimonier, 1978). A progesterone concentration $>1 \mathrm{ng} / \mathrm{ml}$ plasma in a single sample of the series was accepted as evidence of ovulation.

Hormone profiles. Jugular blood was sampled for $6 \mathrm{~h}$, either every $10 \mathrm{~min}$ (ovariectomized animals) or every $20 \mathrm{~min}$ (intact animals) and the plasma was immediately separated and stored at $-18^{\circ} \mathrm{C}$ until assayed. We measured $\mathrm{LH}$ concentrations using the sheep LH assay developed by Pelletier et al. (1982), modified by Montgomery et al. (1985) and validated for goats by Chemineau et al. (1982). All samples from a single experiment were included in the same assay to avoid the problems of inter-assay variation in pulse analysis. The limit of detection was $0.1 \mathrm{ng} / \mathrm{ml}$ and the intra-assay coefficient of variation was $12 \%$.

Progesterone concentrations were measured using the quantitative assay described by Yenikoye et al. (1981), which has a limit of detection of $0 \cdot 1 \mathrm{ng} / \mathrm{ml}$ and intra-assay coefficient of variation of $10 \%$.

Oestradiol-17ß was measured with the assay developed by Thibier \& Saumande (1975). The limit of detection was $2 \mathrm{pg} / \mathrm{ml}$ and the intra-assay coefficient of variation was $11 \%$. Specificity of this assay was verified by normal cross-reaction procedures and also by assaying extracts before and after purification by h.p.l.c. Values for plasma oestradiol- $17 \beta$ in goats include $30-40 \mathrm{pg} / \mathrm{ml}$ in the late follicular phase, $10 \mathrm{pg} / \mathrm{ml}$ in seasonal anoestrus (Chemineau et al., 1982) and $3-4 \mathrm{pg} / \mathrm{ml}$ after ovariectomy (present study). These contrast with values provided by the same assay for the ewe, such as $6 \mathrm{pg} / \mathrm{ml}$ during anoestrus, $3 \mathrm{pg} / \mathrm{ml}$ after ovariectomy and $<\mathrm{l} \mathrm{pg} / \mathrm{ml}$ after combined ovariectomy and adrenalectomy (unpublished).

Experiment 1. Ovarian activity was monitored in 20 intact goats at the onset of the breeding season, from the beginning of August until the end of September. Frequent samples were taken every week throughout the period to allow the study of LH pulse patterns and oestradiol concentrations in the period leading up to the first ovulation. Once a goat had ovulated, it was no longer sampled for $\mathbf{L H}$.

Experiment 2. Eight goats were ovariectomized in July 1983 and 2 months later, on 21 September, 4 of them were given subcutaneous implants containing oestradiol-17 $\beta$ (Sigma, St Louis, MO, U.S.A.). These were made from Silastic tubing (Dow Corning, $3.35 \mathrm{~mm}$ i.d. $4.65 \mathrm{~mm}$ o.d.), basically as described by Goodman et al. (1982), except that they were $2 \mathrm{~cm}$ long and theoretically released $4-5 \mu \mathrm{g}$ oestradiol/day. The animals were intensively sampled on 15 November and were then treated with an intra-vaginal implant containing $350 \mathrm{mg}$ progesterone (I.P. 3893, Intervet SA-ANCA, 49000 Angers, France) as described by Branscheid et al. (1985). The intensive sampling was repeated 11 days later and the intra-vaginal implants were removed. This schedule was repeated during the anoestrous season (25 April and 29 May). 
Experiment 3. A further 11 ovariectomized goats were all given oestradiol implants on 1 March and on 18 March they were placed in a photoperiod-control room under a regimen of long days ( $16 \mathrm{~h}$ light:8 h dark; lights on: 05:30 h) until the end of the experiment. From 15 April, 6 of these animals were injected intramuscularly every day with $2 \mathrm{mg}$ melatonin (Sigma) dissolved in ethanol:water $(10: 90 \mathrm{v} / \mathrm{v})$ (Kennaway \& Seamark, 1980). The injections were given $10 \mathrm{~h}$ after dawn ( $15: 30 \mathrm{~h})$ to simulate the melatonin pattern of short days, a treatment which should theoretically advance the breeding season (Chemineau et al., 1986). The remaining animals served as controls and received injections of vehicle only. The animals were sampled intensively on 3 occasions: on 4 April, during the pre-treatment period; on 23 May, 38 days after the start of treatment; and on 27 June, 72 days after the start of treatment.

Pulse detection and statistical analysis. The serial samples were analysed for LH pulses using the algorithm, 'Pulsar', developed by Merriam \& Wachter (1982). The G parameters (the number of standard deviations by which a peak must exceed the baseline in order to be accepted) were $3.98,2.40,1.68,1 \cdot 24$, and 0.93 for $G_{1}-G_{5}$, these being the requirements for pulses composed of one to five samples which exceed the baseline, respectively. The Baxter parameters describing the parabolic relationship between the concentration of a hormone in a sample and the standard deviation (assay variation) about that concentration were $0.01344\left(b_{1}\right.$, the $y$ intercept), $0.03813\left(b_{2}\right.$, the $x$ coefficient) and $-0.003237\left(b_{3}, x^{2}\right.$ coefficient). The pulse frequency, mean pulse amplitudes (the difference between pulse peak and preceding nadir) and the mean level of $\mathrm{LH}$ were calculated for each profile. They were used in the analysis of treatment effects, which were tested by split-plot analysis of variance (Dagnélie, 1970) and paired $t$ test (Snedecor \& Cochran, 1980).

\section{Experiment 1}

\section{Results}

Ovulation was detected in the first goat at the end of August, in 13 of the 20 goats by midSeptember and in all 20 by the end of September (Fig. 1). In the anovulatory animals, the concentration of oestradiol did not change significantly over the period of observation and remained around $10 \mathrm{pg} / \mathrm{ml}$. There were, however, significant effects of sampling time on the secretion of LH pulses. As the season progressed, average pulse frequency increased progressively such that the frequency at the end of the period was $65 \%$ above the frequency at the beginning $(P<0.01)$. At the same time, the mean level of LH increased by $47 \%(P<0.01)$. Two examples of individual profiles are given in Fig. 2. Statistical analysis also revealed a change in pulse amplitude with time $(P<0.05)$ but the maximum in early September was followed by a fall the following week and so the pattern was not clear.

\section{Experiment 2}

Plasma concentrations of oestradiol were significantly $(P<0.05)$ higher in the goats treated with oestradiol implants (breeding season, $6.5 \pm 0.3 \mathrm{pg} / \mathrm{ml}$; anoestrus, $6.5 \pm 1.0 \mathrm{pg} / \mathrm{ml}$, mean \pm s.e.m.) than in untreated goats (breeding season, $3.4 \pm 1.4 \mathrm{pg} / \mathrm{ml})$. Oestradiol was undetectable $(<2 \mathrm{pg} / \mathrm{ml}$ plasma) in one ovariectomized goat during the breeding season. Similarly, progesterone was undetectable in plasma in the absence of the intravaginal implant, which raised the concentration to $1.33 \pm 0.5 \mathrm{ng} / \mathrm{ml}$. The frequency of LH pulses (Fig. 3) was significantly affected by sampling time $(P<0.01)$ and oestradiol $(P<0.01)$, but not by progesterone (data not shown). Profiles from a control and an oestradiol-treated doe are given in Fig. 4 . The very small effect of season on pulse frequency in the absence of oestradiol ( $5 \%$ lower during anoestrus than during the breeding season) was not statistically significant, but there was a very large effect in the presence of oestradiol $(54 \%$ lower during anoestrus than during the breeding season; $P<0.05$; Fig. 2) and so there was a significant interaction between oestradiol treatment and sampling time $(P<0.01)$. The interaction between oestradiol and sampling time exerted similar effects on the mean levels of LH (Fig. 3; $P<0.01$ ). LH pulse amplitude was significantly (Fig. 3; $P<0.01$ ) higher in goats treated with oestradiol than in untreated goats, but was not affected by season or progesterone.

\section{Experiment 3}

Comparison of the period before melatonin treatment with the subsequent periods demonstrated a significant decrease (by $43 \%$ ) in pulse frequency between the first and the last period $(P<0.01)$ in the control group (Table 1). In contrast, there was a significant increase (by $20 \%$ ) in the melatonintreated group between these same two periods $(P<0.05)$. These effects were not significant when 


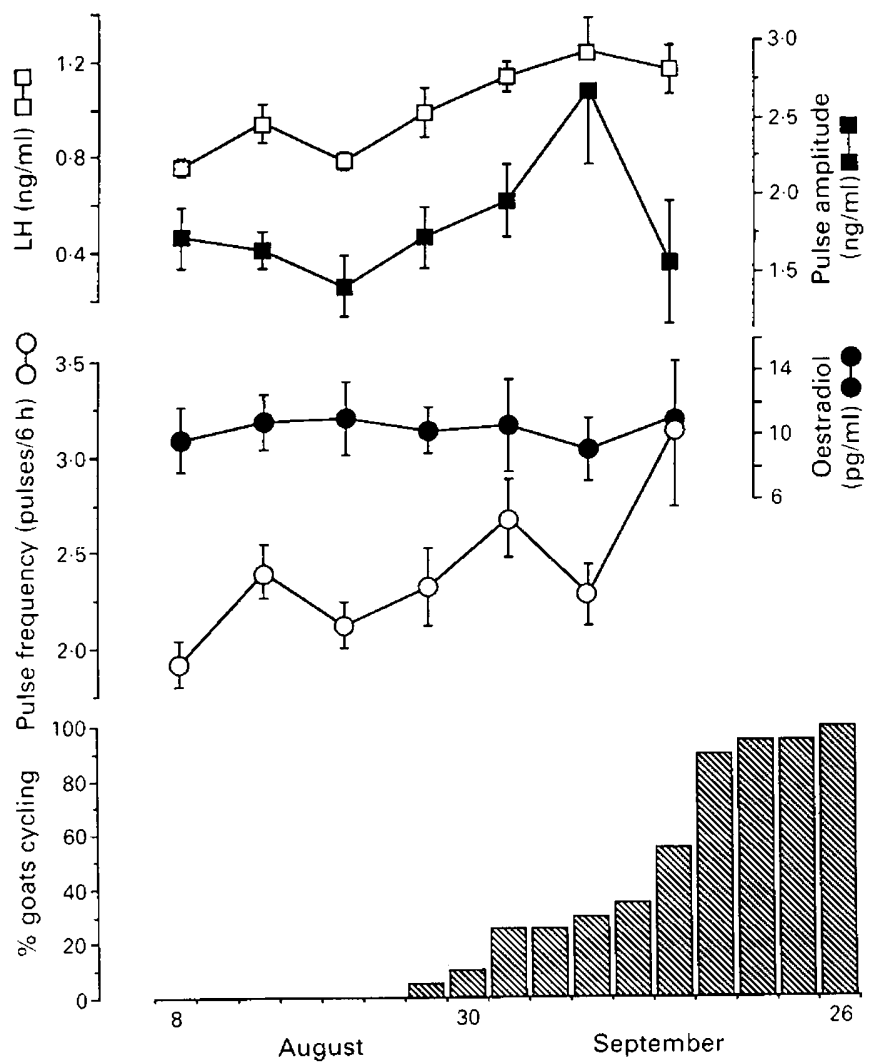

Fig. 1. Relationships between the plasma concentrations of LH and oestradiol in the period leading up to the first ovulation at the onset of the breeding season in entire Saanen dairy goats. Each point on the hormone profiles represents mean \pm s.e.m. for the animals which were still anovulatory when the samples were taken (maximum $n=20$ ).

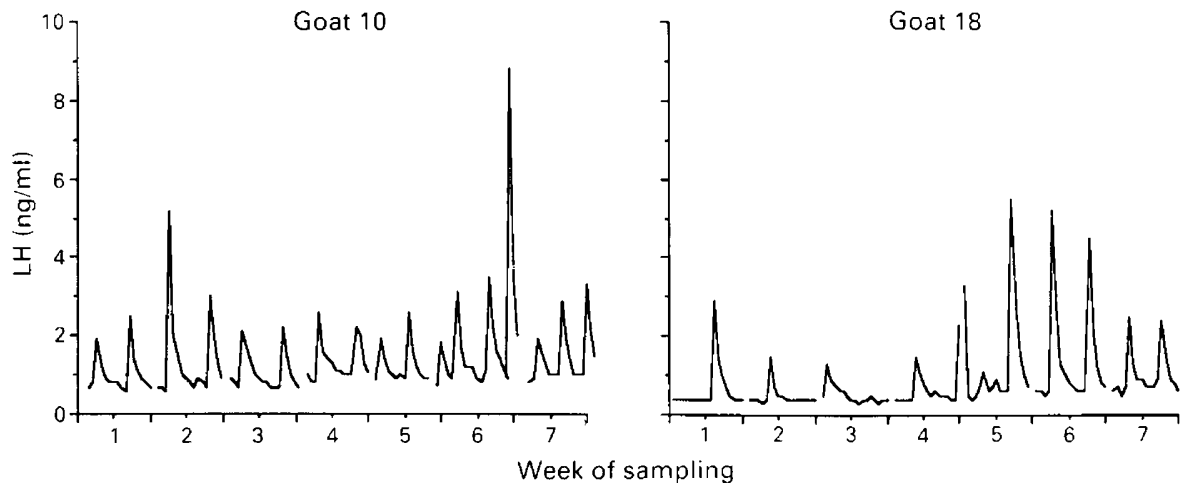

Fig. 2. Weekly plasma $\mathrm{LH}$ profiles from two entire goats in the period leading up to the first ovulation at the onset of the breeding season. 

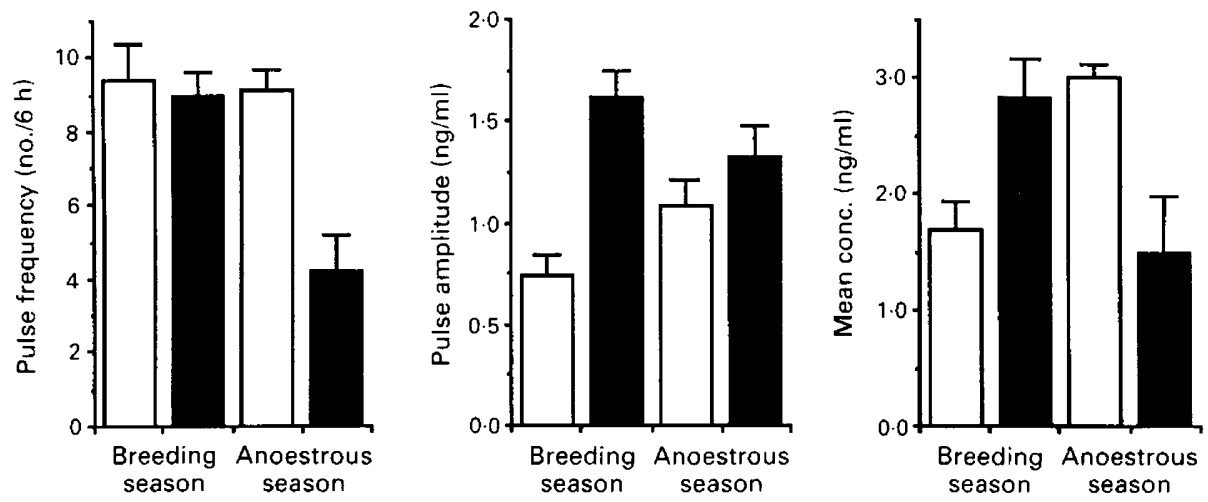

Fig. 3. Effect of oestradiol on the secretion of LH in ovariectomized Saanen goats during the breeding and anoestrous seasons. Values are mean \pm s.e.m. for 4 goats per group. Open columns, no oestradiol; solid columns, + oestradiol.
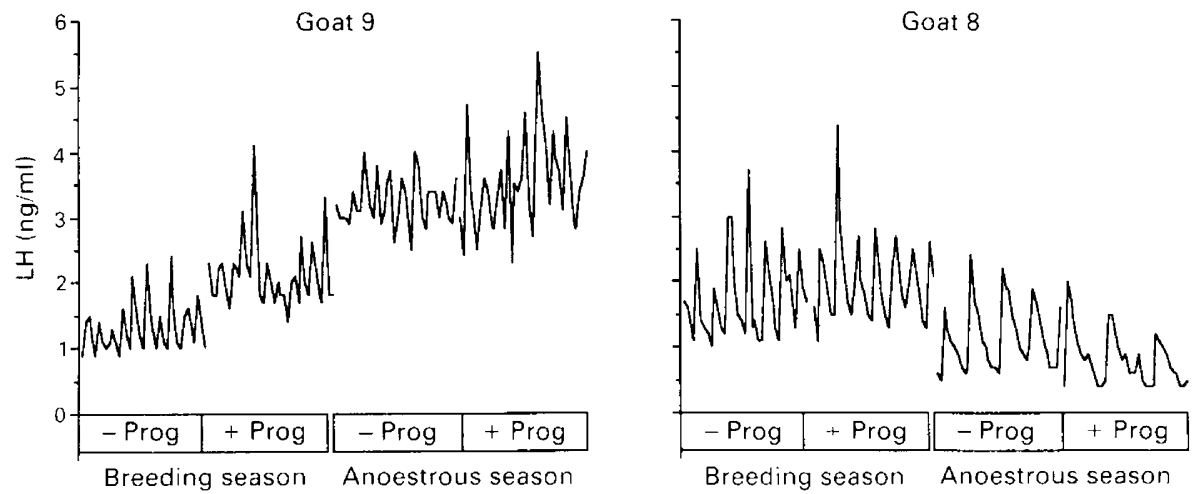

Fig. 4. Plasma LH profiles from an ovariectomized goat (No. 9) and an ovariectomized goat bearing an oestradiol implant (No. 8). The samples were taken every $10 \mathrm{~min}$ for $6 \mathrm{~h}$ during the breeding and anoestrous seasons, before ( - Prog) and during $(+$ Prog) treatment with progesterone.

comparing Periods 1 and 3 with Period 2. The mean concentrations of LH decreased significantly in the control group between the first two periods $(P<0.001)$ and did not fall further thereafter. In the melatonin-treated group, the mean values of LH were similar for all three periods. Pulse amplitude was not significantly modified by melatonin treatment or time.

\section{Discussion}

In intact, seasonally anovulatory goats, the frequency and amplitude of the LH pulses increased as the onset of the breeding season approached. As a consequence, the mean levels of LH increased. This gradual enhancement of gonadotrophic activity would stimulate ovarian folliculogenesis and was therefore probably responsible for the equally gradual onset of cyclic ovarian activity in the group. There was no detectable change in circulating oestrogen levels, perhaps because the change in LH secretion was too subtle to affect the concentration of oestradiol in pooled samples of plasma. Nevertheless, an increase in gonadotrophin secretion in the presence of apparently constant plasma oestradiol concentrations suggests a decline in the responsiveness of the hypothalamus and pituitary 
Table 1. The effect of melatonin on mean LH concentrations and the frequency and amplitude of LH pulses in plasma sampled every $10 \mathrm{~min}$ from ovariectomized goats maintained under long days (16 h light: $8 \mathrm{~h}$ dark)

\begin{tabular}{|c|c|c|c|c|c|c|}
\hline & Period 1 & & Period 2 & & Period 3 & \\
\hline Pulse frequency (pulses $/ 6 \mathrm{~h}$ ) & & (1) vs (2) & & (2) vs (3) & & (1) vs (3) \\
\hline Control & $7 \cdot 0 \pm 2 \cdot 2$ & & $4 \cdot 4 \pm 1 \cdot 1$ & & $4 \cdot 0 \pm 2 \cdot 0$ & $P<0.01$ \\
\hline Melatonin & $4 \cdot 3 \pm 2 \cdot 3$ & & $4 \cdot 8 \pm 2 \cdot 6$ & & $5 \cdot 2 \pm 2 \cdot 0$ & $P<0.05$ \\
\hline \multicolumn{7}{|l|}{ Pulse amplitude ( $\mathrm{ng} / \mathrm{ml}$ ) } \\
\hline Control & $1 \cdot 6 \pm 0.3$ & & $1 \cdot 1 \pm 0 \cdot 5$ & & $1 \cdot 3 \pm 0 \cdot 7$ & \\
\hline Melatonin & $1 \cdot 7 \pm 1 \cdot 2$ & & $1 \cdot 9 \pm 2 \cdot 3$ & & $1 \cdot 2 \pm 0 \cdot 8$ & \\
\hline \multicolumn{7}{|l|}{ Mean conc. $(\mathrm{ng} / \mathrm{ml})$} \\
\hline Control & $2.6 \pm 0.5$ & $P<0.01$ & $1.5 \pm 0.5$ & & $1.5 \pm 0.4$ & $P<0.001$ \\
\hline Melatonin & $2 \cdot 6 \pm 1 \cdot 3$ & & $1.8 \pm 0.9$ & & $2 \cdot 1 \pm 1 \cdot 0$ & \\
\hline
\end{tabular}

Values are mean \pm s.e.m.

All the animals bore subcutaneous oestradiol- $17 \beta$ implants and were injected $10 \mathrm{~h}$ after dawn every day with vehicle (Controls, $N=5$ ) or $2 \mathrm{mg}$ melatonin $(N=6)$. The LH profiles were studied before treatment began (Period 1$)$, after 38 days treatment (Period 2 ) and after 72 days treatment (Period 3 ).

gland to the inhibitory effects of oestradiol. This conclusion is consistent with the experiments with ovariectomized goats, in which seasonal changes in pulse frequency were observed in the animals treated with implants which provide constant circulating concentrations of oestradiol.

The ewe also secretes LH pulses infrequently during the anoestrous season (review: Martin, 1984), although the transition to frequencies characteristic of the breeding season may be more abrupt in the few weeks before ovulatory activity begins (Poulton et al., 1987). Despite this minor difference, it appears that the mechanism underlying the effects of season on reproductive activity is the same for both goats and sheep, namely a change in the responsiveness of the hypothalamus to negative feedback by ovarian steroids (review: Karsch et al., 1984). However, LH secretion in the ovariectomized ewe also appears to be directly affected by photoperiod in the absence of gonadal steroids, an observation which has led to suggestions that steroid-independent pathways are also involved in seasonal reproductive cycles (Goodman et al., 1982; Montgomery et al., 1985). Our data from ovariectomized goats which were not treated with oestradiol suggest that this may not be the case for this species. We interpret this cautiously, however, because the responsiveness of the hypothalamus to season is lost in long-term ovariectomized animals (Montgomery et al., 1985) and the degree to which it is expressed depends largely on the degree of seasonality of the breed under consideration (Martin, 1984). More detailed study, perhaps including other breeds, is therefore required before we could conclude that steroid-independent mechanisms do not exist in goats.

In the present study, the oestradiol implants reduced the frequency of LH pulses in ovariectomized goats by about $50 \%$ during the anoestrous season. This response contrasts with that in ovariectomized ewes treated with identical implants in the same laboratory, in which LH pulses are often completely blocked (Martin et al., 1988). This difference between the species in their responsiveness to negative feedback by oestradiol is reflected in the circulating concentrations of the steroid in intact animals, which appear to be 2-3-fold higher for goats than for sheep (e.g. Karsch et al., 1980; Chemineau et al., 1982).

In ovariectomized goats, the amplitude of the $\mathrm{LH}$ pulses was increased by oestradiol in both the breeding and the anoestrous seasons. Similar effects have been observed in goats in Australia by Sutherland (1987). We expected oestrogen fluctuations to increase in amplitude during anoestrus because a reduction in pulse frequency is generally accompanied by an increase in pulse amplitude, ostensibly because the extra time between pulses allows pituitary stores of LH to accumulate (Martin, 1984). However, a similar effect during the breeding seson was not expected because studies in sheep have suggested that, at that time of year, oestradiol reduces the responsiveness of the anterior pituitary gland to gonadotrophin-releasing hormone $(\mathrm{GnRH})$ and thereby reduces $\mathrm{LH}$ 
pulse amplitude (Goodman \& Karsch, 1980). Why the two species should differ in this aspect, and the consequences of these differences on the reproductive systems, are not clear at this stage. However, these observations do support the suggestion that pulse amplitude does not play a major role in the regulation of ovarian function (Martin, 1984).

Progesterone treatment had remarkably little effect on LH secretion in the ovariectomized goat. Sutherland (1987) used a similar treatment and also found little effect. Superficially, this also appears to contrast with the situation in the ewe, in which progesterone is a major component of the feedback loop controlling LH pulse frequency (review: Martin, 1984). However, LH pulse frequency in intact goats is lower during the luteal phase and increases when progesterone concentrations fall at luteolysis (Sutherland, 1987). In both of the studies with ovariectomized goats, the circulating concentrations of progesterone provided by the implants were low and variable, and failed to reproduce the concentrations $(5-10 \mathrm{ng} / \mathrm{ml})$ normally seen in the intact goat during the luteal phase (Chemineau et al., 1982; Sutherland, 1987). It appears that progesterone does not affect LH pulse frequency in this species unless it is present in the plasma at concentrations of $>3 \mathrm{ng} / \mathrm{ml}$ (Sutherland, 1987) and so the implants were inadequate to test fully the role of progesterone in negative feedback. Again, it is most likely that the goat and ewe are similar, with LH pulse frequency controlled during the luteal phase by a synergistic interaction between progesterone and oestradiol (Martin et al., 1983; Wallace \& McNeilly, 1986). The differences between the species are therefore quantitative rather than qualitative, a supposition which should be tested by studies incorporating dose-responses for the steroids.

In Exp. 3, the imposition of long days led to a gradual decline of $\mathrm{LH}$ pulse frequency in ovariectomized goats treated with oestradiol. Daily treatment with melatonin, injected at an hour chosen to reproduce the duration of short-day secretion of this pineal hormone, inhibited this decrease and ultimately led to frequencies which differed significantly between the groups. This effect supports the contention that the duration of melatonin secretion is involved in controlling the hypothalamic system which commands the release of pulses of gonadotrophin-releasing hormone in the goat, as it does in the ewe (Bittman et al., 1985; Karsch et al., 1984; Hansen, 1985). The species do appear to differ, however, in the delay between the initiation of short-day (or melatonin) treatment and the LH or ovulatory response. For the dairy goat, this delay is at least 70 days (Mori et al., 1982; Chemineau et al., 1986; P. Chemineau, unpublished data) and so is about 25 days longer than for the ewe (Karsch et al., 1984; Thimonier, 1986). This probably explains the lack of a significant effect of melatonin injections after 38 days of treatment in the present study.

In conclusion, the data presented here suggest that the effects of season on reproduction in the sheep and goat are mediated by similar mechanisms. It appears that a change in the duration of the night-time melatonin pattern alters the hypothalamic responsiveness to oestradiol, and this leads to changes in the frequency of LH pulses. A low pulse frequency switches off the reproductive system and a high frequency switches it on.

We thank B. Mirman and P. Pignon for their help during the experiment, and Agnès Daveau, Françoise Maurice, D. Andre and Claudette Fagu for their help with the hormone assays. While in France, G.B.M. was supported by an Overseas Study Award from the Australian Meat Research Committee.

\section{References}

Bissonnette, T.H. (1941) Experimental modification of breeding cycles in goats. Physiol. Zool. 14, 379-383.

Bittman, E.L. (1984) Melatonin and photoperiodic time measurement: evidence from rodents and ruminants. In The Pineal Gland, pp. 155-192. Ed. R. J. Reiter. Raven Press, New York.

Bittman, E.L., Kaynard, A.H., Olster, D.H., Robinson, J.E., Yellon, S.M. \& Karsch, F.J. (1985) Pineal melatonin mediates photoperiodic control of pulsatile luteinizing hormone secretion in the ewe. Neuroendocrinology 40, 409-418.

Branscheid, Von W., Libal, U. \& Holtz, W. (1985) Die Wirkung verschedener intravaginaler Implantate auf das Scheidenmilieu beim Schaf. Zuchthygiene 20, 87-99.

Chemineau, P., Gauthier, D., Poirier, J.C. \& Saumande, J. (1982) Plasma levels of LH, FSH, prolactin, oestradiol-17 $\beta$ and progesterone during natural and 
induced oestrus in the dairy goat. Theriogenology 17, 313-323.

Chemineau, P., Normant, E., Ravault, J.P. \& Thimonier, J. (1986) Induction and persistence of pituitary and ovarian activity in the out-of-season lactating dairy goat after a treatment combining a skeleton photoperiod, melatonin and the male effect. J. Reprod. Fert. 78, 497-504.

Dagnélie, P. (1980) Théorie et Méthodes Statistiques, Volume 2., p. 451. Presses Agronomiques de Gembloux, Gembloux, Belgium.

Goodman, R.L. \& Karsch, F.J. (1980) Pulsatile secretion of luteinizing hormone: differential suppression by ovarian steroids. Endocrinology 107, 1286-1290.

Goodman, R.L., Bittman, E.L., Foster, D.L. \& Karsch, F.J. (1982) Alterations in the control of luteinizing hormone pulse frequency underlie the seasonal variation in estradiol negative feedback in the ewe. Biol. Reprod. 27, 580-589.

Hansen, P.J. (1985) Photoperiodic regulation of reproduction in mammals breeding under long days versus mammals breeding under short days. Anim. Reprod. Sci. 9, 301-315.

Herbert, J. (1981) The pineal gland and photoperiodic control of the ferret's reproductive cycle. In Biological Clocks in Seasonal Reproductive Cycles, pp. 261-276. Eds B. K. Follett \& D. E. Follett. Scientechnica, Bristol.

Hoffmann, K. (1981) The role of the pineal gland in the photoperiod control of seasonal cycles in hamsters. In Biological Clocks in Seasonal Reproductive Cycles, pp. 237-250. Eds B. K. Follett \& D. E. Follett. Scientechnica, Bristol.

Karsch, F.J., Legan, S.J., Ryan, K.D. \& Foster, D.L. (1980) Importance of estradiol and progesterone in regulating $\mathrm{LH}$ secretion and estrous behavior during the sheep estrous cycle. Biol. Reprod. 23, 404-413.

Karsch, F.J., Bittman, E.L., Foster, D.L., Goodman, R.L., Legan, S.J. \& Robinson, J.E. (1984) Neuroendocrine basis of seasonal reproduction. Recent Prog. Horm. Res. 40, 185-232.

Kennaway, D.J. (1984) Pineal function in ungulates. Pineal Res. Reviews 2, 113-140.

Kennaway, D.J. \& Seamark, R.F. (1980) Circulating level of melatonin following it's oral administration or subcutaneous injection in sheep and goats. Aust. J. biol. Sci. 33, $349-353$.

Legan, S.J., Karsch, F.J. \& Foster, D.L. (1977) The endocrine control of seasonal reproductive function in the ewe: a marked change in the response to the negative feedback action of estradiol on luteinizing hormone secretion. Endocrinology 101, 818-824.

Martin, G.B. (1984) Factors affecting the secretion of luteinizing hormone in the ewe. Biol. Rev. 59, 1-87.

Martin, G.B., Scaramuzzi, R.J. \& Henstridge, J.D. (1983) Effects of oestradiol, progesterone and androstenedione on the pulsatile secretion of luteinizing hormone in ovariectomized ewes during spring and autumn. J. Endocr. 96, 18 I-193.

Martin, G.B., Price, C.A., Thiéry, J-C. \& Webb, R. (1988) Interactions between inhibin, oestradiol and progesterone in the control of gonadotrophin secretion in the ewe. J. Reprod. Fert. 82, 319-328.

Merriam, G.R. \& Wachter, K.W. (1982) Algorithms for the study of episodic hormone secretion. Am. J. Physiol. 243, 310-318.

Montgomery, G.W., Martin, G.B. \& Pelletier, J. (1985) Changes in pulsatile LH secretion after ovariectomy in Ile-de-France ewes in two seasons. J. Reprod. Fert. 73, 173-183.

Mori, Y., Takahashi, M., Sawasaki, T. \& Kano, Y. (1982) Significance of long-day conditions for the institution of annual cycles in the female goat. In Proc. $7 \mathrm{th}$ Asia and Oceania Congr. Endocrinology, Tokyo, pp. 381385. Eds K. Shizume, H. Imura \& N. Shimizu. Excerpta Medica, Amsterdam.

Pelletier, J., Garnier, D.H., de Reviers, M.M., Terqui, M. \& Ortavant, R. (1982) Seasonal variation in LH and testosterone release in rams of two breeds. J. Reprod. Fert. 64, 341-346.

Poulton, A.L., English, J., Symons, A.M. \& Arendt, J. (1987) Changes in plasma concentrations of LH, FSH and prolactin in ewes receiving melatonin and short-photoperiod treatments to induce early onset of breeding activity. J. Endocr. 112, 103-111.

Scaramuzzi, R.J. \& Martensz, N.D. (1975) The effects of active immunization against androstenedione on luteinizing hormone levels in the ewe. In Immunization with Hormones in Reproductive Research, pp. 141-152. Ed. E. Nieschlag. North-Holland, Amsterdam.

Snedecor, G.W. \& Cochran, W.G. (1980) Statistical Methods, 6th edn. Iowa State University Press, Ames.

Sutherland, S.R.D. (1987) Effects of oestradiol and progesterone on $\mathrm{LH}$ secretion during anoestrus and the breeding season in ovariectomized angora-cross does. Proc. 4th AAAP Anim. Sci. Congr., Hamilton p. 230, Abstr.

Terqui, M. \& Thimonier, J. (1974) Nouvelle méthode radioimmunologique rapide pour l'estimation $\mathrm{du}$ niveau de progestérone plasmatique. Application pour le diagnostic précoce de la gestation chez la brebis et la chèvre. C. r. hebd. Séanc. Acad. Sci., Paris. D 279, 1109-1112.

Thibier, M. \& Saumande, J. (1975) Oestradiol-17ß, progesterone and $17 \alpha$-hydroxyprogesterone concentrations in jugular venous plasma in cows prior to and during oestrus. J. Steroid Biochem. 6, 1433-1437.

Thimonier, J. (1978) L'activité ovarienne chez les bovins. Moyen d'étude et facteurs de variation. Annls Méd. vét. 122, 81-92.

Thimonier, J. (1986) Périodes anovulatoires chez les mammifères domestiques. Definition et rôle des facteurs de l'environnement. In Recherches Récentes sur l'Epidemiologie de la Fertilité, pp. 143-158. Eds J. Henry-Suchet, M. Minitz \& Spira. Masson, Paris.

Wallace, J.W. \& McNeilly, A.S. (1986) Changes in FSH and the pulsatile secretion of LH during treatment of ewes with bovine follicular fluid throughout the luteal phase of the oestrous cycle. J. Endocr. 111, 317-327.

Yenikoye, A., Maribua, J.C., Ley, J. P., Jolivet, E., Terqui, M. \& Lemou-Resplandy, M. (1981) Modèle mathématique de l'évolution de progestérone chez la vache: application et mise en évidence de différences entre races. Reprod. Nutr. Dévelop. 21, 561-575.

Yuthasastrakosol, P., Palmer, W.M. \& Howland, B.E. (1977) Release of LH in anoestrous ewes and cyclic ewes. J. Reprod. Fert. 50, 319-321.

Received 9 June 1987 